\title{
The HIV Gap in National AIDS Statistics
}

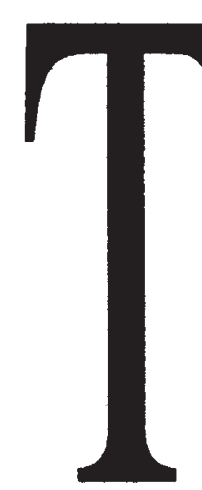

he HIV-AIDS hypothesis rests on the assertion that all AIDS cases are associated with HIV (Confronting AIDS-Update 1988,Natl.Acad.Sci.Press, Wash., D.C.; Blattner, W., et al., 1988, Science 241, 514-515; Weiss, R. and Jaffe, $H$., 1990, Nature 345, 659-660; Duesberg, P.H., 1992, Pharmacol. Ther. 55, 201277). Therefore, the Centers for Disease Control (CDC) groups American AIDS cases in its HIVI AIDS Surveillance into "exposure (to HIV) categories." However, there are no national AIDS statistics that document the natural coincidence between AIDS diseases and HIV. Contrary to its title, the HIVIAIDS Surveillance of the CDC does not report HIV tests. Correlations between HIV and AIDS can only be determined from individual studies and from those $C D C$ AIDS case report forms that include HIV tests.

But most "HIV tests" measure antibodies against HIV rather than the virus itself. And antibodies are not unambiguous evidence for the presence of a virus, nor are they rational predictors for viral disease. Instead antibodies neutralize HIV and restrict the virus to latency. This is the reason that leading AIDS researchers have had notorious difficulties in isolating HIV, even in people dying from AIDS (Weiss, R., 1991, Nature 349, 374; Cohen, J., 1993, Science 259, 168-170).

Moreover, antibody tests generatefalse-positive results if an epitope is shared between different organisms. According to a recent review entitled "HIV testing: State of the Art," "depending on the population tested, 20 to 70 $\%$ of. . .two successive positive ELISAs (enzyme-linked immunosorbent assay) are confirmed by Western blot (an alternative antibody assay)." (Sloand, E. M., et al., 1991, JAMA 266, 2861-2866).

In a population with a low probability of infection, the false-positive rate is high. According to the widely cited study of applicants to the U.S. Army by Burke et al., $83 \%$ of all initially positive ELISAs $(10,000 / 12,000)$ were false-positives (New Eng. J. Med. 319, 961-964, 1988).

In a population with a high incidence of infection, however, the false-positive rate is expected to be low. Therefore the CDC assumes that "the tiny proportion of possibly false-positive screening tests in persons with AIDS-indicative diseases is of little consequence" (Confronting AlDS -Update 1988). But this is not observed.

For example, one study documented 131 repeatedly ELISA-positive homosexual men withnegative Westem blots in a cohort of 4,994 homosexuals of which $37 \%$ were HIV-positive (Phair, J., et al., 1992, J. AIDS 5, 988 992). Another study "found HIV-1 infection in only 4 (12.5\%) of 32 high-risk cases" with repeatedly positive ELISAs (Celum, C. L., et al., 1991, J. Infect. Dis. 164,

\author{
PETER H. DUESBERG
}

656-664). HIV infection was negative by Western blot, provirus amplification with the polymerase chain reaction (PCR), and virus isolation tests. Another study identified 33 ELISA-positive and even Western blotpositive subjects who were HIV-negative based on the PCR test for HIV DNA (Schechter, M., etal., 1991, AIDS $5,373-379)$. These subjects were from a group of 316 homosexuals of which 158 (50\%) were PCR-positive.

The relatively high incidence of false-positive HIV antibody tests in these HIV risk groups probably reflects the presence of antibodies to other viruses and microbes that may cross-react with HIV. For example, 7 out of 10 blood donors treated with an influenza virus vaccine in 1991 became HIV ELISA-positive. Each of these proved to be false-positives upon confirmation with a Western blot (Mac Kenzie, W. R., et al., 1992, JAMA 268, 10151017). Since the CDC “... accepts a reactive screening test for HIV antibody without confirmation by a supplemental test. .." (Confronting AIDS -Update 1988) and does not request a repeatedly positive antibody test in its "AIDS adult confidential case report" forms, it includes false-positives in its HIVIAIDS Surveillance.

In fact, the CDC even includes AIDS cases in its HIVI AIDS Surveillance "without laboratory evidence regarding HIV infection" (Confronting AIDS-Update 1988). Upon request, the CDC's director of the HIV/AIDS division, Harold Jaffe, stated that the HIV status of 43,606 out of the 253,448 American AIDS cases recorded by the end of 1992 was "not tested"(per. com., 1993). However this figure seems to be an understatement. Obviously, all 10,360 American AIDS cases diagnosed before the HIV antibody test, i.e., before 1985, were not tested (HIV/ AIDS Surveillance, February 1993). In addition, the CDC published that "Approximately one third of AIDS patients in the United States have been from New York and San Francisco, where, since 1985, $>7 \%$ have been reported with HIV-antibody test results, compared with $>60 \%$ in other areas." (ConfrontingAIDS-Update 1988). Thus, between 1985 and $1987,58 \%(93 \%$ x $1 / 3+40 \%$ $x 2 / 3$ ) of the 56,807 AIDS cases recorded in that period, or 32,948 , have not been tested. For 1988, the CDC reported that $27 \%$ or 9,039 of the 33,480 AIDS cases recorded for that year were not tested for HIV (Selik, R. M., et al., 1990, J. AIDS 3, 73-82). According to the CDC's Technical Information Activity, 3682 AIDS cases without an HIV-test were recorded in 1989, 2888 in 1990 , 1960 in 1991, and 1395 in 1992 (per. com., 1993). Thus, at least 62,272 , or 18,666 more than Jaffe reports, were not tested.

Determination of the HIV-AIDS correlation is further obscured because HIV-free AIDS cases are not recorded in the CDC's HIVIAIDS Surveillance. By 1993, at least 4621 HIV-free AIDS cases had been documented in the
Peter $H$. Duesberg is a professor in the department of molecular \& cell biology at the University of California at Berkeley, Berkeley, $C A$ 94720. The views expressed here are the author's own, and not necessarily those of Bio/Technology. 


\section{/THE LAST WORD}

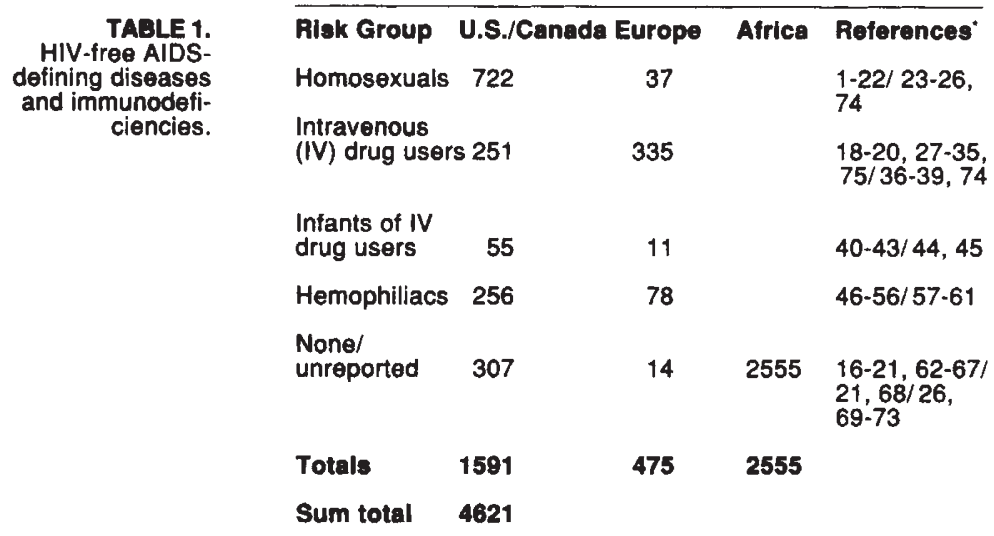

* References for risk group categories from each continent are separated by slashes.

References: 1. Drew, W. L., et al. (1985), Ann. Intern. Med. 103, 61-63. 2. Weber, J. N., et al (1986), Lancet i, 1179-1182. 3. Novick, D. M., et al. (1986), J. Hepatol. 3, 363-370. 4. Collier, A.C et al. (1987), Am. J. Med. 82, 593-601. 5. Bartholomew, C., et al. (1987), J. Am. Med. Assoc. 257, 2604-2608. 6. Buimovici-Klein, E., et al. (1988), J.Med.Virology 25, 371-385.7. Afrasiabi R., et al. (1986), Am. J. Med. 81, 969-973. 8. Bowden, F. J., et al. (1991), Lancet 337, 1313 1314. 9. Safai, B., et al. (1991), Kaposi's sarcoma among HIV-negative high risk population, VII Intemational Conference on AIDS (Florence, Italy) 10. Castro, A., et al. (1992), Lancet 339, 868. 11 . 10. Castro, A., et al. (1992), Lancet 339, 868. 11 .
Huang, Y. Q., et al. (1992), Lancet 339, 515-518. 12. Friedman-Kien, A.E., etal.(1990), Lancet 335, 168-169. 13. Marion, S. A., et al (1989), J.Acquir. Immune Defic. Syndr. 2, 178-186. 14. Kaslow, R A., et al. (1989), JAMA 261, 3424-3429. 15. Macon, W. R., etal. (1993), AlDS Weekly April,12,15. 16. Laurence, J, etal (1992), Lancet 340, 273-274. 17. Smith, D. K., et al. (1993), New Eng. J. Med. 328, 373-379.18. Ho, D.D.,etal.(1993), New Eng. 328,373-379.18. Ho, D. D.,etal.(1993), New Eng.
J. Med. 328, 380-385. 19. Theuer, C. P., et al. (1990),J.Infect.Dis. 5, 399-405.20. Shafer, R. W., et al. (1991), AIDS 5, 399-405. 21. Centers for Disease Control (1992), Morbid. Mort. Weekly Report 41, 541-545. 22. Lang, W., et al. (1989), $J$. Acquir. Immune Defic. Syndr. 2, 63-69. 23. Marquart, K.-H.,etal.(1991), AIDS S, 346-348.24. Archer, C. B., et al. (1989), Clin. Exper. Dermatol. Archer, C. B., et al. (1989), Clin. Exper. Dermatol. 14, 233-236. 25. Lowdell, C. P., et al. (1989), J.
Royal Soc.Med. 82,226-227.26. Brun-Vezinet, F., et al. (1984), The Lancet i, 1253-1256. 27 Stonebumer, R. L., et al. (1988), Science 242,916 919. 28. Selwyn, P. A., et al. (1988), AIDS 2, 267272. 29. Braun, M. M., et al. (1989), JAMA 261 393-397. 30. Donahoe, R.M., etal. (1987),Ann.NY Acad. Sci. 496, 711-721. 31. Savona, S., et al. Acad. Sci. 496, 711-721. 31. Savona, S., et al.
(1985), Ann. Intern. Med. 102, 737-741. 32. Des Jarlais, D. C., et al. (1988), in AIDS and IV Drug Abusers: Current Perspectives, R. P. Galea, B. F. Lewis, L. Baker, Eds. (National Health Publishing, Owings Mills, MD), pp. 97-109. 33. Munoz, A.. et al. (1992), J. Acquir. Immune Defic. Syndr. 5, 694 700 34 Brudney K Dis. 144, 744-749. 35. Weiss, S. H., et al, (1992) The Lancet 340, 608-609. 36. Espinoza, P., et al.

(1987), Gastroenterologie Clinique et Biologique 11, 288-292, 37. Mientjes, G. H., et al. (1991) 11, 288-292. 37. Mientjes, G. H., et al. (1991), AIDS 5, 35-41. 38. Mientjes, G. H., et al. (1992), AIDS 6, 207-212. 39. Mientjes, G. H. C., et al.
(1993), Br.Med.J.306,371-373.40. Koch, T. K., et al. (1990), Ann. Neurol. 28, 456-457. 41. Duesberg, P. H. (1992), Pharmacol. Ther. 55, 201-277. 42. Rogers, M. F., et al. (1989), New Eng. J. Med. 320, 1649-1654 43. Culver, K.W., etal. (1987),J.Pediatr. 111,230-235.44.Blanche, S., et al. (1989), New Eng. J. Med. 320, 1643S., et al. (1989), New Eng. J. Med. 320, 1643Med. 311, 1269-1273. 46. Tsoukas, C., et al. (1984), New Eng. J. Med. 311, 1514-1515. 47. Sullivan, J. L., et al. (1986), J. Pediatr. 108, 504510.48. Kreiss,J.K., etal. (1986), Am.J.Med.80, 345-350. 49. Gill, J. C., et al. (1986), J. Pediatr. 108, 511-516. 50. Sharp, R. A., et al. (1987), $J$. Clin. Pathol. 40,849-852.51. Matheson, D.S., et al. (1987), Clin. Immunol. Immunopathol. 4, 41al. (1987), Clin. Immunol. Immunopathol. 4, 41tology 25, 14-19.53. Jin, Z., et al. (1989), Allergy Clin. Immunol. 83, 165-170.54. Lang, D. J., et al. (1989), J. AIDS 2, 540-549. 55. Becherer, P. R. et al (1990) Am J. Hematol 34, 204-209. 56 Jas. (1990), Am. Hemal. 34, 204-209. 56 269. 57. Ludlam, C. A., et al. (1985), Lancet ii, 233-236. 58. AIDS-Hemophilia French Study Group (1985), Blood 66, 896-901. 59. Madhok, R., et al. (1986), Br. Med. J. 293, 978-980. 60. Mahir, W.S., et al.(1988), Br.J.Haem., 69,367370. 61. Antonaci, S., et al. (1988), Diagn. Clin. Immunol. 5, 318-325. 62. Pitchenik, A. E., et al. (1987), Am. Rev. Respir. Dis. 135, 875-879. 63. Pitchenik, A. E. et al. (1990), Lancet 336, 440Pitchenik, A. E., et al. (1990), Lancet 336, 440520-524. 65. Gupta, S., et al. (1992), Proc. Natl. Acad. Sci. USA 89, 7831-7835. 66. Spira, T. J., et al. (1993), New Eng. J. Med. 328, 386-392. 67. Duncan, R. A., et al. (1993), N. Eng. J.Med 328 , 393-398. 68. Kaczmarski, R. S., et al. (1992), Lancet 340,608 . 69. Widy-Wirski, R., et al. (1988), JAMA 260, 3286-3289.70. De Cock, K. (1988), JAMA 260, 3286-3289. 70. De Cock, K. Taelman, H., et al. (1991), Br.Med.J. 302, 1206. 72. Hishida, $O$., et al. (1992), Lancer 340,971 972. 73. Brindle, R. J., et al. (1993), Am. Rev. Respir. Dis. 147, 958-961. 74. Mienties, G.H.C. etal.(1992), Br.J.Haem. 82,615-619.75. Koury, M. J. (1990), Am. J. Hem. 35, 134-135.

U.S., Europe, and Africa with the clinical AIDS definition(Table 1). Even Jaffe, again upon request, reported 89 HIV-free AIDS cases (per. com., 1993). The cases recorded in Table 1 suffered from one or more of the over 25 heterogeneous AIDS-defining diseases and from AIDS-defining immunodeficiencies without diseases. Some of these proved to be HIV-free even by PCR amplification of viral RNA and DNA.

Table 1 includes some American and European immunodeficiencies that may not exactly fit the current defini- tion of AIDS defining immmunodeficiency without disease, which is 200 T-cells per microliter (CDC, 1992, MMWR 41, RR17, 1-19), as for example, HIV-free male homosexuals on various recreational drugs with " $<600$ cells per cubic millimeter" (Table 1, ref. 14) or HIVnegative hemophiliacs with T4/T8 cell ratios of about 1 or $<1$ (Table 1, refs. 46-61). But even if not all of these cases fit the current definition of AIDS-defining immunodeficiency exactly, they do so prospectively. This is because their T-cells typically continue to decline either because of risk behavior, such as the consumption of recreational drugs, or because of clinical AIDS risks, such as chronic transfusion of foreign proteins as prophylaxis against hemophilia (Duesberg, P.H. 1992, op. cit.).

Since a clinical definition is used in Africa , statistics from this continent are not biased against HIV-free AIDS. For example, 2215 out of 4383 (50.5\%) African AIDS patients from Abidjan, Ivory Coast, Lusaka, Zambia, and Kinshasa, Zaire, were HIV-antibody negative (Table 1, ref. 70,71). Another study using antibody tests and supplementary PCR tests for HIV reports 135(59\%) HIV-free AIDS patients from Ghana out of 227 suffering from weight loss, diarrhea, chronic fever, tuberculosis, and neurological diseases (Table 1, ref. 72). Only 37 (30\%) of a group of 122 African tuberculosis patients were HIV-positive, according to a study published in 1993 (Table 1, ref. 73). An earlier study documents 116 HIV-negatives among 424 African patients, and Montagnier et al. diagnosed HIV in four out of eight (Table 1, ref. 26, 69). It follows that about $50 \%$ of the African AIDS cases, or 65,000 of the 129,000 diagnosed by 1992 (Duesberg,P.H., 1992,op.cit.), may be HIV-free and thus not caused by HIV.

Instead of considering the potential usefulness of HIVfree AIDS cases in the search for the cause of AIDS, the CDC and the NIH's director for AIDS research hid in 1992 the then rapidly growing numbers of HIV-free AIDS cases (Duesberg, P.H., 1992, op. cit.) under a new name, "idiopathic CD4 lymphocytopenia" or ICL. Indeed, the new name has sent HIV-free AIDS cases into obscurity. But efforts to set apart HIV-free from HIVpositive AIDS cases by the new term are not based on clinical or scientific arguments. According to an editorial by Anthony Fauci, HIV-free AIDS or ICL cases are unlike the HIV-positive cases because (1) "Given the heterogeneity of the [ICL] syndrome, it is highly likely that there is no common cause," and because (2) "Approximately one-third of the patients are women, as compared with $11 \%$ among those with HIV ... [in America ]" (Fauci, A., 1993,New Eng.J.Med.328,429-431). Yet proponents of the HIV hypothesis, including Fauci, insist that HIV is the common cause of the more than 25 heterogeneous AIDS diseases and that HIV causes African AIDS, although about $50 \%$ of the African patients are women (Duesberg, P.H., 1992, op. cit.).

In view of the above, I submit that the natural coincidence between HIV and AIDS in America and Europe remains unknown, and is certainly less than perfect. Thus arguments for the etiological role of HIV in AIDS, which assume a perfect correlation, are fundamentally flawed. 